\title{
PENGEMBANGAN MODUL PEMBELAJARAN IPA SMP PADA MATERI TEKANAN BERBASIS KETERAMPILAN PROSES SAINS
}

\author{
Friska Octavia Rosa \\ Pendidikan Fisika FKIP Universitas Muhammadiyah Metro \\ Email: friska@teachers.org
}

\begin{abstract}
Abstrak
Penelitian ini bertujuan untuk merancang dan menyusun modul pembelajaran IPA berbasis keterampilan proses sains dan menguji efektivitas modul terhadap hasil belajar dan motivasi siswa. Penelitian ini merupaan penelitian penelitian Educational Reseach and Development. Pengembangan modul ini menggunakan model 4D dengan tahapan define, design, development dan disseminate. Modul IPA yang dikembangkan menggunakan keterpaduan model connected. Modul yang dikembangkan berbasis keterampilan proses sains, yang meliputi mengamati, mengklarifikasi, mengkomunikasi, mengukur, memprediksi dan menyimpulkan. Hasil penelitian menunjukkan bahwa terdapat peningkatan hasil belajar serta peningkatan keterampilan proses sains siswa. Hasil penelitian menunjukkan bahwa modul sangat membantu siswa belajar mandiri, membantu dan diperlukan siswa sebagai panduan belajar dimana dilengkapi dengan eksperimen-eksperimen sederhana. Pengembangan modul IPA berbasis KPS ini dinilai efektif karena selain hasil belajar siswa yang meningkat, keterampilan proses sains dari siswa itu sendiri mengalami peningkatan.
\end{abstract}

Kata Kunci: Modul, Keterampilan Proses Sains

\begin{abstract}
The aims of this reseach is to design and develop a science module based on science process skills and to test the effectiveness of the module to students' learning achievement and motivation. This research is Educational Reseach and Development. The development of this module used 4D models. The stage are define, design, development and disseminate. Science module is developed using a model of integration connected. Modules which developed based on science process skills includes observing phase, classifying phase, communicating phase, measuring phase, predicting phase and concluding phase used on science process skills includes. The results showed that there were increasing students' learning achievement and increasing students' science process skills. Development of sciencebased KPS module consider effective because in addition to increasing student learning outcomes, science process skills of the students themselves have increased.
\end{abstract}

Keywords: Module, Science Process Skills 


\section{PENDAHULUAN}

Pendidikan memiliki peranan yang penting dalam proses pembangunan suatu bangsa. Dunia pendidikan diharapkan dapat memberikan sumber daya manusia yang profesional untuk memajukan negara dengan ilmu dan teknologinya. John Dewey dalam. Poedjiadi (2010:67) menyatakan bahwa “tiap negara bertujuan agar setiap anggota masyarakat dapat dikembangkan kemampuannya dalam bidang fisik, intelektual, dan moral secara demokratis". Pendapat tersebut menguatkan bahwa setiap individu dalam setiap negara memiliki kesempatan untuk memperoleh pendidikan yang baik. Tujuan tersebut juga didukung bahwa setiap individu memiliki kemampuan dan kreativitas yang berbeda, sehingga kemampuankemampuan tersebut dapat dikembangkan lebih bermakna lagi.

IPA merupakan ilmu yang berkembang dari pengamatan gejalagejala alam dan interaksi yang terjadi di dalamnya. IPA dapat diterapkan dalam kehidupan sehari-hari seperti peristiwa respirasi, tekanan darah, kapal selam, balon udara, penggangkat hidrolik, pompa hidrolik, jembatan ponton dan sebagainya. Dengan demikian IPA merupakan ilmu pengetahuan yang sangat dekat dengan kita. Selain itu, IPA juga mendasari perkembangan teknologi, seperti pendapat Poedjiadi (2010: 64) bahwa "sains juga dapat berperan dalam meningkatkan pengetahuan masyarakat tentang penggunaan sumber daya alam atau meningkatkan pemahaman masyarakat tentang gejala alam dalam kehidupan sehari-hari mereka".

IPA merupakan ilmu yang berkaitan dengan cara mencari tahu tentang fenomena alam serta sistematis, sehingga IPA bukan hanya penguasaan kumpulan ilmu pengetahuan yang berupa fakta-fakta, konsep-konsep atau prinsip-prinsip saja, tetapi juga merupakan suatu proses penemuan. Hal tersebut menunjukkan bahwa pembelajaran IPA merupakan suatu ilmu yang harus dipelajari melalui pengamatan langsung. Tidak semua materi dapat disampaikan atau cocok menggunakan metode ceramah. Hal tersebutlah yang menjadi salah satu faktor kurang maksimalnya prestasi siswa dalam pembelajaran. Sesuai 
Friska Octavia Rosa- Pengembangan Modul Pembelajaran...

dengan anjuran yang dicanangkan oleh UNESCO 1996 dalam. Poedjiadi (2010: 98) bahwa "pembelajaran formal maupun nonformal diharapkan dapat memberi pengelaman bagi pesertanya melalui learning to know, learning to do, learning to be and learning to live together". Pendapat tersebut menguatkan bahwa pembelajaran IPA merupakan pembelajaran yang mudah dipelajari melalu pengamatan langsung. Sedangkan fakta hasil observasi di lapangan menunjukkan bahwa sebagian guru masih menggunakan metode ceramah dalam penyampaian materi pembelajaran di kelas. Sedangkan setiap materi pembelajaran memiliki karakteristik yang berbeda sehingga tidak semua tepat menggunakan metode ceramah dalam penyampaian materinya.

Faktor-faktor yang diungkapkan di atas memberi kesimpulan bahwa perlu adanya suatu inovasi dalam proses pembelajaran, salah satunya adalah dengan pembuatan bahan ajar sesuai dengan karakteristik materi yang akan disampaikan. Menurut Ibrahim dalam Trianto (2012: 98) bahwa "Bahan ajar merupakan seperangkat materi/substansi pembelajaran (teaching material) yang disusun secara sistematis, mencerminkan kompetensi yang akan dikuasai siswa dalam kegiatan pembelajaran”. Pendapat tersebut menjelaskan bahwa dalam suatu bahan ajar harus terdapat kesesuaian dengan karakteristik masing-masing materi.

Menurut Briggs dalam Arif dkk. (2010: 6) bahwa "media adalah segala alat fisik yang dapat menyajikan pesan serta merangsang siswa untuk belajar. Buku, film, kaset, film bingkai adalah contoh-contohnya". Salah satu media ajar yang dapat digunakan siswa untuk belajar mandiri adalah dalam bentuk modul. "Modul merupakan bahan ajar yang dapat digunakan oleh siswa untuk belajar secara mandiri dengan bantuan seminimal mungkin dari orang lain" (Munadi, 2010: 99). Pendapat-pendapat tersebut menjelaskan bahwa dalam proses pembelajaran dibutuhkan media untuk menarik perhatian dan rasa ingin tahu siswa terhadap pelajaran, salah satu media yang dapat dikembangkan adalah berupa modul karena dapat digunakan siswa untuk belajar mandiri. Terlebih sebagai bahan untuk belajar mandiri, pengembangan modul ini 
Friska Octavia Rosa- Pengembangan Modul Pembelajaran...

mendukung penerapan kurikulum centered) dan terkait dengan 2013, dimana guru dituntut untuk permasalahan kehidupan sehari-hari. membimbing siswa untuk lebih aktif Padilla dalam Keil (2009) bahwa dalam pembelajaran. Aydinli (2011) keterampilan sebagai kemampuan menyatakan bahwa "kurikulum dipindahtangankan, sesuai dengan menyarankan bahwa banyak aktivitas berbagai disiplin ilmu, dan sains membutuhkan keterampilan mencerminkan perilaku ilmuwan serta proses sains dengan mengharapkan menekankan bahwa proses ilmiah guru menggunakan strategi meliputi keterampilan baik dasar dan pembelajaran inkuiri”. Kurikulum 2013 terintegrasi. Rauf dkk. (2013) menekankan pada aktivitas siswa, menyatakan bahwa "dalam sains, sehingga pengembangan modul adalah keterampilan proses sains dasar salah satu pendukung dari membantu anak-anak untuk keterlaksanaan kurikulum 2013.

mengembangkan pembelajaran mereka

Dengan pengembangan modul melalui pengalaman". Kemudian IPA berbasis keterampilan proses sains Dimyati dan Mudjiono (2013: 140) ini, siswa diharapkan mampu menjelaskan bahwa "keterampilanmengembangkan keterampilan- kete- keterampilan dasar terdiri dari enam rampilan berupa mengamati, meng- keterampilan, yakni: mengobservasi, klasifikasi, mengkomunikasikan, mengklasifikasi, memprediksi, mengmengukur, memprediksi dan ukur, menyimpulkan, dan mengmenyimpulkan dalam proses proses komunikasi”. Sesuai pendapatpembelajaan untuk membuktikan suatu pendapat tersebut, setiap siswa harus konsep, dengan begitu siswa akan memiliki keterampilan-keterampilan berperan aktif dan tertarik sehingga dasar dalam pembelajaran IPA, motivasi belajarnya akan meningkat, sehingga keterampilan proses sains begitu pula dengan hasil belajarnya. tersebut dikemas dalam modul Proses pembelajaran idealnya dapat pembelajaran yang nantinya dapat melibatkan siswa secara aktif. membantu siswa mengembangkan Pendekatan pembelajaran yang inovatif keterampilan proses sainsnya secara itu berpusat pada siswa (student mandiri. 
Friska Octavia Rosa- Pengembangan Modul Pembelajaran...

Berdasarkan uraian latar rencanaan (design), tahap pengembelakang di atas, maka dilakukan bangan (development) dan tahap penelitian dengan judul "Pengem- penyebaran (disseminate). Model bangan Modul Pembelajaran IPA ketepaduan yang digunakan pada SMP/MTs Berbasis Keterampilan pengembangan modul berbasis Proses Sains". Penelitian ini bertujuan keterampilan proses sains ini adalah untuk merancang dan menyusun modul model Connected (keterhubungan). pembelajaran IPA berbasis Instrumen pengumpulan data pada keterampilan proses sains, serta penelitian ini adalah dengan metode tes menguji efektivitas modul terhadap dan angket. hasil belajar siswa.

\section{HASIL DAN PEMBAHASAN}

\section{METODE}

Penelitian ini merupakan penelitian Educational Reseach and Development (R\&D) yaitu metode penelitian yang digunakan untuk menghasilkan suatu produk pendidikan, dan menguji keefektifan produk tersebut dalam bidang pendidikan. Penelitian yang dilakukan merupakan pengembangan bahan ajar berupa modul pembelajaran IPA SMP kelas VIII pada materi tekanan. Model pengembangan sistem perangkat pembelajaran yang digunakan adalah model Thiagarajan. Model Thiagarajan terdiri dari 4 tahap yang dikenal dengan model 4D (four D model). Keempat tahap tersebut adalah tahap pendefinisian (define), tahap pe- keahlian dari masing-masing guru.
Tahapan pertama yaitu define, dilakukan observasi di lapangan dengan menyebarkan angket serta melakukan wawancara dengan siswa dan guru mengenai pembelajaran IPA di sekolah. Berdasarkan hasil pengisian angket dan wawancara didapatkan data bahwa pembelajaran IPA di sekolah hanya menggunakan buku pegangan dari sekolah yang siswa pinjam dari perpustakaan sekolah. Buku pegangan yang digunakan siswa dan guru pun belum menggunakan buku IPA terpadu. Pembelajaran yang diterapkan sudah menggunakan team teaching tapi pada kenyataannya pembelajaran di kelas masih dilakukan secara bergantian sesuai dengan bidang 
Friska Octavia Rosa- Pengembangan Modul Pembelajaran...

Materi IPA yang akan tersebut dikarenakan dengan dikembangkan adalah materi tekanan, mengajarkan mereka keterampilan dimana pada silabus disebutkan pada proses sains (KPS) maka mereka dapat Kompetensi Dasar (KD) 3.8 dan 4.8 mempelajari pengetahuan itu sendiri. yang merupakan keterpaduan antara Pendapat dari Young ini mempertegas materi fisika, biologi dan kimia. bahwa pentingnya pembelajaran Sehingga pengembangan modul IPA berbasis keterampilan proses sains ini mengangkat tema tekanan, alasan diterapkan dalam pembelajaran di memilih tema tersebut adalah sekolah pada siswa. Keterampilan banyaknya aplikasi dalam kehidupan Proses Sains (KPS) yang digunakan sehari-hari yang dekat dengan siswa dalam pengembangan modul pada materi tekanan. Sehingga pembelajaran IPA ini adalah KPS dasar diharapkan akan lebih memudahkan (basic skills). Hasil penelitian siswa dalam mempelajari modul dan Akinyemi dkk. (2010) menguatkan materi yang akan disajikan. Cronbach bahwa pada tingkat pendidikan dasar dalam Suryabrata (2012: 231) me- dan menengah keterampilan yang lebih nyatakan bahwa bahwa pembelajaran baik dikembangkan adalah itu ditunjukkan pada perubahan sikap keterampilan dasar. Seperti diketahui sebagai hasil dari pengalaman. bahwa salah satu fungsi modul adalah Berdasarkan pendapat tersebut me- sebagai panduan siswa dalam belajar nguatkan bahwa pembelajaran yang mandiri, sehingga keterampilan dasar baik dan efektif adalah ketika siswa sesuai dengan kebutuhan dan diberi pengalaman atau diajak kemampuan siswa pada tahap melakukan percobaan-percobaan yang pendidikan dasar. Modul IPA berbasis membuat proses pembelajaran lebih KPS ini dibuat sebagai buku pegangan bermakna.

Young dalam Mei (2007) siswa untuk belajar mandiri yang di dalamnya terdapat eksperimenmenyatakan bahwa mengajarkan siswa eksperimen sederhana dengan alat-alat mengenai fakta sains tidak sama yang sederhana pula sehingga dapat pentingnya dengan perkembangan dilakukan oleh siswa secara mandiri di keterampilan proses sains mereka. Hal rumah tanpa harus melakukannya di 
Friska Octavia Rosa- Pengembangan Modul Pembelajaran...

laboratorium IPA di sekolah. Sehingga presentase yang tinggi dari siswa dengan begitu pembelajaran IPA menunjukkan bahwa keterampilan diharapkan akan lebih bermakna.

proses telah membuat mereka lebih

Tahapan kedua yaitu design, sadar mengenai relevansi dari sains Tahap ini merupakan tahapan dalam hidup mereka.

perancangan produk berupa modul

Tahapan ketiga adalah develope, pembelajaran IPA berbasis kete- pada tahap ini dilakukan tahapan rampilan proses sains menggunakan validasi, uji coba terbatas dan uji coba model keterpaduan connected kelas. Tahapan pengembangan ini (keterhubungan). Menurut Rustaman bertujuan untuk menghasilkan sebuah dkk. dalam Nuroso dkk.(2010) bahwa produk modul IPA berbasis ketekelebihan model pembelajaran terpadu connected adalah siswa akan lebih mudah menemukan keterkaitan karena masih dalam lingkup satu bidang studi. Pembuatan modul IPA ini menggunakan pendekatan keterampilan proses sains yang meliputi tahap mengamati, mengklasifikasi, mengkomunikasi, mengukur, memprediksi dan menyimpulkan. Berdasarkan pendapat tersebut menguatkan bahwa pembelajaran yang baik dan efektif adalah ketika siswa diberi pengalaman atau diajak melakukan percobaanpercobaan yang membuat proses pembelajaran lebih bermakna. Kemudian Mei (2007) mendapatkan hasil penelitian bahwa ditemukan peningkatan yang signifikan mengenai kompetensi keterampilan dan rampilan proses sains yang sudah siap nantinya untuk disebarkan atau diujicobakan lebih luas lagi setelah dilakukan revisi sesuai dengan validasi dan revisi pada tahap uji coba. Produk berupa draf modul I divalidasi oleh 2 orang dosen ahli, 2 orang guru senior dan 2 orang teman sejawat. Secara lengkap tersaji pada tabel 1.

Setelah draf modul I divalidasi dan direvisi sesuai dengan saran para validator maka draf modul II siap diujicobakan pada kelompok kecil. Pada penelitian ini, kelompok kecil yang digunakan sebanyak 10 orang dan bertujuan untuk mengetahui keterbacaaan modul dan respon siswa terhadap modul yang dikembangkan. Berdasarkan angket didapatkan data bahwa masih perlu dilakukan perbaikan 
Friska Octavia Rosa- Pengembangan Modul Pembelajaran...

pada tata tulis dan bahasa modul serta ditujukan untuk mengetahui pengaruh melengkapi gambar yang mendukung modul terhadap hasil belajar dan materi pada modul. Setelah modul draf motivasi belajar siswa, sehingga II direvisi maka didapatkan modul draf dibutuhkan kelas eksperimen dan kelas III. Modul draf III digunakan untuk uji kontrol untuk membandingkan coba kelas, yaitu uji coba besar yang seberapa besar peningkatan yang lebih luas dari sebelumnya. Uji coba terjadi dengan penggunaan modul IPA besar di lakukan di SMP Negeri 3 berbasis keterampilan proses sains Batanghari dengan menggunakan 2 dibandingkan dengan kelas kontrol. kelas, yaitu kelas VIII.3 dan VIII.5.

Digunakan 2 kelas karena penelitian

Tabel 1. Hasil Validasi Modul

\begin{tabular}{|c|c|c|c|}
\hline Aspek & Sumber & Skor & Kriteria \\
\hline \multirow[t]{6}{*}{ Materi } & Dosen Ahli I & 89 & Cukup \\
\hline & Dosen Ahli 2 & 82 & Cukup \\
\hline & Guru IPA 1 & 114 & Baik \\
\hline & Guru IPA 2 & 109 & Baik \\
\hline & $\begin{array}{l}\text { Teman } \\
\text { Sejawat } 1\end{array}$ & 87 & Cukup \\
\hline & $\begin{array}{l}\text { Teman } \\
\text { Sejawat } 2\end{array}$ & 92 & Cukup \\
\hline \multicolumn{2}{|c|}{ Rata-Rata Skor } & 95,5 & Cukup \\
\hline \multirow[t]{6}{*}{ Kegrafikan } & Dosen Ahli I & 114 & Cukup \\
\hline & Dosen Ahli 2 & 113 & Cukup \\
\hline & Guru IPA 1 & 146 & Baik \\
\hline & Guru IPA 2 & 141 & Baik \\
\hline & $\begin{array}{l}\text { Teman } \\
\text { Sejawat } 1\end{array}$ & 115 & Cukup \\
\hline & $\begin{array}{l}\text { Teman } \\
\text { Sejawat } 2\end{array}$ & 119 & Cukup \\
\hline \multicolumn{2}{|c|}{ Rata-Rata Skor } & 124,7 & Baik \\
\hline
\end{tabular}


Friska Octavia Rosa- Pengembangan Modul Pembelajaran...

Modul IPA berbasis keterampilan proses sains dibuat dengan eksperimeneksperimen sederhana yang dapat siswa lakukan sendiri di rumah. Modul tersebut membantu siswa untuk belajar mandiri,sesuai dengan fungsi modul,yaitu sebagai panduan siswa untuk belajar mandiri. Sebagaimana diungkapkan Munadi (2010: 99) bahwa "modul dibuat berdasarkan program pembelajaran yang utuh dan sistematis serta dirancang untuk sistem pembelajaran mandiri”. Sedangkan Anderson (2002) dalam Chabalengula dkk. (2012) menyatakan bahwa "keterampilan proses sains merupakan bagian penting dari penyelidikan ilmiah dan akibatnya meningkatkan literasi sains di kalangan siswa”.

Berdasarkan data-data hasil penelitian dapat disimpulkan bahwa hasil belajar pada kelas eksperimen lebih baik dibandingkan dengan kelas kontrol, dimana pada kelas eksperimen siswa diberikan perlakuan dengan penambahan media berupa modul IPA berbasis keterampilan proses sains.Data ini didukung oleh hasil penelitian dari Ango (2002) yang menyatakan bahwa kerja praktek meningkatkan kualitas dan tingkat pemahaman ilmiah yang dicapai siswa. Pengalaman untuk siswa sekolah dalam studi mereka dipandu ilmu pengetahuan harus mencakup pengalaman yang mempromosikan keterampilan proses, seperti mengukur, mengamati, mengklasifikasi dan memprediksi. Kemudian hasil penelitian dari Pummawan (2007) menyebutkan bahwa penggunaan modul adalah salah satu sarana untuk mengembangkan kemampuan kognitif siswa. pendapat-pendapat tersebut mendukung hasil penelitian yang telah dilakukan terhadap efektitivitas dari pengembangan modul yang dilakukan.

Ranah kognitif siswa rata-rata yang didapatkan kelas eksperimen adalah 70 dan pada kelas kontrol 60,8 sedangkan KKM yang ditetapkan pada sekolah adalah sebesar 65. Hasil ini tentu memberikan gambaran bahwa modul yang dikembangkan dibutuhkan oleh siswa dan guru dalam proses pembelajaran untuk mendapatkan hasil yang maksimal. Modul yang dikembangkan merupakan buku pelengkap atau penunjang siswa untuk belajar mandiri, sehingga membantu siswa dalam memahami materi yang diajarkan guru di sekolah. 
Friska Octavia Rosa- Pengembangan Modul Pembelajaran...

Modul yang dikembangakan pembelajaran yang dilakukan siswa berbasis keterampilan proses sains menggunakan modul IPA yang yang meliputi keterampilan mengamati, dikembangkan. Berdasarkan hasil mengklasifikasi, mengkomunikasi, pengamatan, didapatkan hasil seperti mengukur, memprediksi, dan menyim- pada tabel 2 yang memberikan pulkan. Pada uji coba besar di kelas gambaran mengenai keterampilan eksperimen, dilakukan pengamatan proses sains siswa ketika menggunakan mengenai keterlaksanaan keterampilan- modul IPA yang dikembangakan dalam keterampilan tersebut pada proses pembelajaran.

Tabel 2 Hasil Keterampilan Proses Sains

\begin{tabular}{|c|l|c|c|c|}
\hline \multirow{2}{*}{ No } & \multirow{2}{*}{ Keterampilan } & \multicolumn{3}{|c|}{ Pertemuan } \\
\cline { 3 - 5 } & & $\mathbf{1}$ & $\mathbf{2}$ & $\mathbf{3}$ \\
\hline 1. & Mengamati & 59 & 48 & 67 \\
\hline 2. & Mengklasifikasi & 58 & 55 & 63 \\
\hline 3. & Mengkomunikasi & 44 & 57 & 65 \\
\hline 4. & Mengukur & 56 & 58 & 65 \\
\hline 5. & Memprediksi & 56 & 48 & 64 \\
\hline 6. & Menyimpulkan & 59 & 54 & 68 \\
\hline
\end{tabular}

Berdasarkan data pada tabel 2 lingkup yang paling sederhana, yaitu maka dapat dilihat bahwa pada aspek pengertian tekanan secara umum serta keterampilan mengamati, meng- fungsi gigi pada manusia. Pada materi klasifikasi, memprediksi dan tersebut siswa sudah sering menyimpulkan mengalami penurunan mendapatkan materi pembelajaran skor pada pertemuan kedua, tetapi tersebut sejak duduk di bangku sekolah kembali mengalami peningkatan pada dasar, sehingga materi pada pertemuan pertemuan ketiga. Salah satu penyebab pertama yaitu tekanan memiliki hal tersebut adalah materi pada karakteristik paling sederhana pertemuan pertama memiliki ruang dibandingkan dengan tekanan pada zat 
Friska Octavia Rosa- Pengembangan Modul Pembelajaran...

cair dan gas. Sedangkan pada aspek materi pembelajaran, menunjukkan mengkomunikasikan dan mengukur, hasil 100\% dari sampel setuju atau pada setiap pertemuan mengalami menjawab "ya". Pada kelengkapan peningkatan. Berdasarkan data gambar untuk menunjang materi yang tersebut, modul hasil pengembangan disampaikan didapatkan $87 \%$ yang diterapkan pada siswa baik menyatakan sudah lengkap, kemudian digunakan untuk meningkatkan $83 \%$ siswa menyatakan modul sudah keterampilan proses sains pada aspek menarik. Selain pengisiian angket mengkomunikasi dan mengukur. keterbacaan, siswa diberikan angket Kedua aspek tersebut didukung oleh respon yang skor rata-rata diperoleh modul yang dibuat dengan melengkapi dari pengisian angket respon tersebut dengan eksperimen-eksperimen adalah 22 atau dengan kategori sangat sederhana yang dapat dilakukan siswa baik. Modul draf III ini kemudian secara mandiri, sehingga modul dilakukan revisi sesuai dengan respon tersebut memberikan suatu rangsangan motivasi dan rasa ingin tahu siswa meningkat.

Tahapan ini juga melakukan dan kesulitan dan kendala yang terjadi selama proses uji coba besar. Setelah direvisi maka didapatkan modul draf IV yang siap untuk penyebaran yang penyebaran angket respon dan lebih luas lagi.

keterbacaan modul, diberikan pada Tahapan keempat adalah kelas eksperimen yang menggunakan disseminate,Pada tahap ini dilakukan modul IPA berbasis keterampilan penyebaran di 16 Sekolah Menengah proses sains. Angket tersebut Pertama yang ada di Kabupaten dimaksudkan untuk mengetahui Lampung Timur. Penyebaran dilakukan bagaimana respon siswa terhadap pada guru-guru IPA dan diberikan penggunaan modul dan untuk angket responden. Dari hasil mengetahui keterbacaan modul tersebut penyebaran tersebut guru memberikan oleh siswa. Hasil pengisiian angket penilaian terhadap pengembangan keterbacaan modul oleh siswa hasilnya modul IPA berbasis keterampilan sudah baik. Pada tata tulis, bahasa dan proses sains pada materi tekanan manfaat modul untuk memahami tersebut. Hasil penilaian dan tanggapan 
Friska Octavia Rosa- Pengembangan Modul Pembelajaran...

guru-guru IPA rata-rata sebesar 16,36.

Rentang nilai tersebut termasuk dalam

kategori sangat baik.

\section{PENUTUP}

\section{Kesimpulan}

Hasil analisis dan pembahasan hasil penelitian, maka dapat disimpulkan bahwa Karakteristik modul IPA berbasis keterampilan proses sains dengan tema tekanan yang terdiri dari mengamati, mengklasifikasi, mengkomunikasi, mengukur, memprediksi dan menyimpulkan. Modul ini menggunakan model keterpaduan connected pada materi tekanan menggabungkan antara materi fisika, biologi dan kimia karena modul ini dibuat sesuai dengan kurikulum 2013 dimana pembelajaran IPA bersifat terpadu. Hasil penelitian menunjukkan bahwa modul sangat membantu siswa belajar mandiri, membantu dan diperlukan siswa sebagai panduan belajar dimana dilengkapi dengan eksperimen-eksperimen sederhana. Pengembangan modul IPA berbasis KPS ini dinilai efektif karena selain hasil belajar siswa yang meningkat, keterampilan proses sains dari siswa itu sendiri mengalami peningkatan.

\section{Saran}

Kepada guru mata pelajaran IPA untuk lebih variatif dalam penggunaan metode pembelajaran yang sesuai dengan materi yang akan disampaikan. Serta perlu dikembangkan modul-modul pembelajaran yang dapat digunakan sebagai panduan siswa dalam belajar mandiri sebagai salah satu sarana pembelajaran. Kepada peneliti yang lain disarankan untuk mengembangkan modul pembelajaran dengan tema yang berbeda dan pengembangan modul IPA berbasis KPS ini dapat dijadikan acuan pengembangan modul yang lebih baik lagi. Pengembangan modul ini hanya dilakukan di satu sekolah dengan menggunakan kelas eksperimen dan kelas kontrol untuk mengetahui keefektifan modul, sehingga disarankan peneliti berikutnya untuk menguji keefektifan modul di beberapa sekolah. Peneliti selanjutnya juga disarankan untuk membuat modul pegangan guru dan pegangan siswa secara terpisah, agar pembelajaran lebih optimal.

\section{DAFTAR PUSTAKA}

Arief S. Sardiman, et. al. (2010). Media Pendidikan. Jakarta: PT Rajagrafindo Persada. 
Friska Octavia Rosa- Pengembangan Modul Pembelajaran...

Akinyemi, Olofunminiyi. (2010). Analysis of Science Process Skills in West African Senior Secondary School Certificate Physics Practical Examination in Nigeria. America_eurasian Journal of Scientific Reseach 5 940: 234-240, 2010 ISSN 18186785.

Poedjiadi, Anna. (2010). Sains dan Teknologi Masyarakat. Bandung: PT Remaja Rosdakarya

Ango, L. Mary. (2002). Mastery of Science Process Skills and Their Effective Use in the Teaching of Science: An Educology of Science Education in Nigerian Context. International Journal of Educology, 2002, 16 (1), 11-30.

Aydinli, Emek, dkk. (2011). Turkish Elementary School Students' Performance on Integrated Science Process Skills.Procedia Social and Behavioral Sciences. 15(2011), 3469-3475.

Chabalengula, Mweene Vivien. (2011).

How Pre-service Teachers' Understand and Perform Science

Process Skills.Eurasia Journal of Mathematics, Science \&

Technology Education, 2012, 8(3), 167-176 ISSN: 1305-8223.

Dimyati, Mudjiono. (2013). Belajar \& Pembelajaran. Jakarta: Rineka Cipta.

Harto Nuroso, Joko Siswanto. (2010). Model Pengembangan Modul IPA Terpadu Berdasarkan Perkembangan Kognitif Siswa. $J P 2 F, 1$ (1), 35-46.
Keil, Chris, dkk.(2009). Improvements in Student Achievement and Science Process Skills Using Environmental Health Science Problem-Based Learning Curricula.Electronic Journal of Science Education. 13(1).

Mei, Yew Teo Grace. (2007). Promoting Science Process Skills and the Relevance of Science through Science ALIVE! Programme. Proceedings of Redesigning Pedagogy: Culture, Knowladge and Understanding Conference,Singapore.Environme ntal \& Science Education. 3(1), 30-34 ISSN 1306-3065.

Pummawan, Archaree. (2007). The Development of An E-Learning Module on The Sandy Shores Ecosystem For Grade-8 Secondary Students. Educational Journal of Thailand, 1(1), 95110.

Rauf, Abd Amnah Rose, dkk. (2013). Inculcation of Science Process Skills in a Science Classroom. Canadian Center of Science and Education, Asian Social Science: 9(8),ISSN 1911-2017 E-ISSN 1911-2025.

Suryabrata, Sumadi. 2008. Psikologi Kepribadian. Jakarta: Raja Grafindo Persada

Trianto. (2013). Model Pembelajaran Terpadu. Jakarta: Bumi Aksara.

Munadi, Yudhi. (2010). Media Pembelajaran. Jakarta: Gaung Persada (GP) Press. 